
\title{
Impact of Setbacks on Interior Daylighting in Residential Buildings: A Case Study of Vijayawada, India
}

\author{
M. Kranti Kumar and Natraj Kranthi \\ School of Planning and Architecture, Vijayawada - 521104, Andhra Pradesh, India; \\ kranti.myneni@spav.ac.in, natraj@spav.ac.in
}

\begin{abstract}
Background/Objectives: Efficient day lighting in the residential buildings has several physiological and psychological benefits, particularly contributing to visual comfort. Setbacks and window openings play a major role in admission of day lighting into the buildings. However in general, many spaces inside the buildings most frequently suffer from inefficient day lighting due to inadequate setbacks and window sizes. Given this background, this paper is a scholastic attempt to assess the impact of building setbacks on the window sizes, so as to achieve comfortable day lighting. Methods/Analysis: For this purpose, day lighting in two differently oriented independent residential buildings located in Vijayawada (India) having different setbacks was studied. The day lighting contours were calculated using a Lux Meter at different timings of the day in each of the functional spaces /rooms of the buildings. Also, the interior natural illumination levels in different rooms of the buildings were analyzed against the required standard illumination levels as recommended by The National Building Code of India 2005and the local building byelaws. Findings: The spaces inside buildings suffering from inadequate day lighting were identified. Application/Improvements: Based on the day lighting analysis, design recommendations for window sizes with reference to the respective building setbacks were suggested.
\end{abstract}

Keywords: Building Setbacks, Day Lighting, Obstructions, Residential Buildings, Window Sizes

\section{Introduction}

Day lighting is one of the key design considerations of modern architecture. It affects the design of spaces, energy use, visual and thermal comfort of the user. It has many physiological and psychological benefits. ${ }^{1}$ Windows play a significant role not only in admitting the daylight into the building's interior but also as openings that provide view to the outside world. 2 Window's position, opening size, the room's shape, depth and the color of internal surface determine the interior daylighting. ${ }^{3}$ Besides, various external factors such as local climate, building location, surrounding buildings, building orientation, and daylight factor and daylight autonomy are the decisive factors of climate based designs. ${ }^{4}$

\subsection{Contextual Background}

In India, the development control rules or the building byelaws prescribe the minimum setbacks around the building depending upon the approach road width, plot size and building height. However, day lighting is not considered. Besides, strict adherence to the traditional design principles is often a cause for hindrance in the admission of comfortable day lighting. This phenomenon can be witnessed, particularly, in the coastal regions of the Indian state of Andhra Pradesh (AP) located in the warm and humid climatic zone. (Insert Figure 1 here).

Vastu Shastra, a traditional Hindu system of architecture in India, is most frequently followed in residence design, without which the designs in general are not

${ }^{*}$ Author for correspondence 
acceptable to the users. A strong belief in the traditional principles of design in turn paved way for stereotyped designs with stereotyped setbacks and window sizes. These stereotyped designs usually are either east facing or west facing, with more setbacks on the eastern and northern sides than the western and the southern sides respectively. The setbacks are provided with least consideration to day lighting admission. The traditional design principles of Vastu Shastra are based on the five elements of nature (also called Panchabhootas) i.e., water (northeast), fire (south east), earth (southwest), air (northwest), space/ sky (centre).

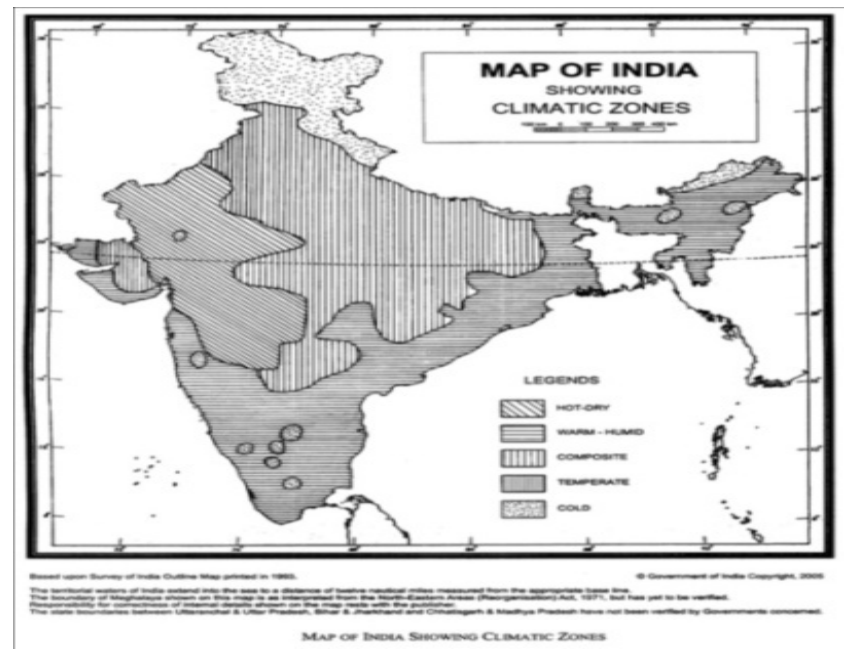

Figure 1. Map of India showing climatic zone Source: National Building Code 2005.

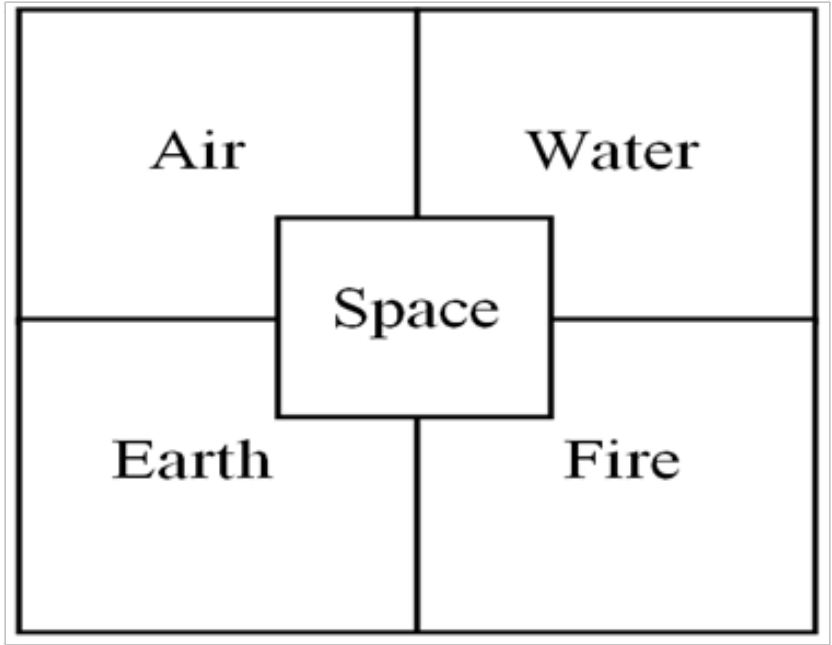

Figure 2. Vastu Shastra's five elements of nature.

In line with this, functional spaces of the residence in general are designed as follows: entrance/ drawing hall on the northeast (for east facing buildings) and northwest (for west facing buildings), kitchen on the southeast, master bedroom on the southwest, children bedroom on the northwest, living hall in the centre. ${ }^{5}$ As a result of these stereotyped designs, day lighting in the building interior spaces is being compromised and is very often less than the minimum illumination levels (in the each of the functional spaces) recommended by the National Building Code (NBC) of India 2005.

Table 1. Recommended values of illumination

\begin{tabular}{|l|l|}
\hline Type of interior or activity & $\begin{array}{l}\text { Recommended values of } \\
\text { illumination }\end{array}$ \\
\hline Reading (casual) & 150 \\
\hline Dining & 100 \\
\hline Cooking & 200 \\
\hline Sleeping & 100 \\
\hline $\begin{array}{l}\text { Home work and sustained } \\
\text { reading }\end{array}$ & 300 \\
\hline Bathrooms & 100 \\
\hline Entrance Halls/Living & 150 \\
\hline Source: IS 3646 (Part 2) 1996
\end{tabular}

Given this background, there is a need to provide setbacks, design internal spaces of the residence and windows so as to admit comfortable day lighting. Therefore, this calls for a need to understand the impact of setbacks on the day lighting. This can further enable in evolving guidelines for window design, for achieving comfortable interior natural illumination levels.

\subsection{Setbacks and Window Openings}

Setback is the space between the building line and the site boundary. As per the National Building Code of India 2005 , a setback line is a line usually parallel to the plot boundaries and laid down in each case by the Authority, beyond which nothing can be constructed towards the site boundaries. ${ }^{6}$ As construction is not permitted with the setback area, increased setback indicates increased obstruction distance. Therefore, setback is one of the key determinants of indoor day lighting. The daylight performance was assessed in the identified residence located in the city of Dhaka (Bangladesh). ${ }^{?}$ Day lighting was evaluated in the south side residential rooms with respect to the changing obstruction distances and the changing window opening sizes. Interior day lighting was found 
to be greatly affected by the obstruction distances and the window sizes, indicating that a comfortable interior delighting can be achieved with an effective control on them. Further, a study on delighting in the tall residential buildings of Mumbai (India) revealed that the upper level floors have higher outdoor and indoor luminance than the lower floors. Larger window openings at the lower floors achieve higher average illumination levels. Interior day lighting is indirectly proportional to the square of the distance from the obstructions. Besides, surrounding adjoining buildings and the landscape elements affect the amount of daylight entering a house. Interiors textures and finishes of materials play a vital role for a room to be naturally illuminated. $\underline{8}$

Windows with low sills increase solar gains, while high window sills limit direct view to streets. Skylight offers better daylight luminance and uniformity than the side light. However, side light offers better visual contact to exterior space than the sky light. .9 About $27.59 \%$ of the annual energy consumption can be saved by choosing the best orientation, optimum window size, shading device, and optimum insulation thickness..$^{10}$ Light shelves significantly contribute today lighting in a building and can help in daylight optimization. During the low daylight seasons, light shelves can contribute to the enhancement of indoor day lighting facilitating the natural light diffusion. 11 Therefore, understanding the variation of indoor illumination levels with respect to the setback can be helpful in window designing (shape and size of openings) so as to achieve comfortable day lighting in different functional space of the building.

\section{Materials and Methods}

\subsection{Study Area}

In order to investigate the impact of the building setbacks on the indoor day lighting, a case study in the coastal city of Vijayawada, AP was taken up. One of the key challenges was to understand the variations in indoor day lighting due to the setback/obstruction distances, while minimising the influence of other factors such as window openings, building shape and size, material, wall texture, wall colour, etc. Therefore, two identical independent residences. But of different orientations i.e., east facing residence and west facing residence $\left(80^{\circ} 42 \times 29.14 » \mathrm{E}\right.$, $16^{\circ} 29>1.40 » \mathrm{~N}$ ). From a gated community (Vasant Vihar) located in the Poranki locality of the city were chosen.

It was ensured that these residences were identical in plan, material (interior and exterior), wall texture and wall paint. The plans of both these residences are in accordance with the traditional design principles of Vastu Shastra.

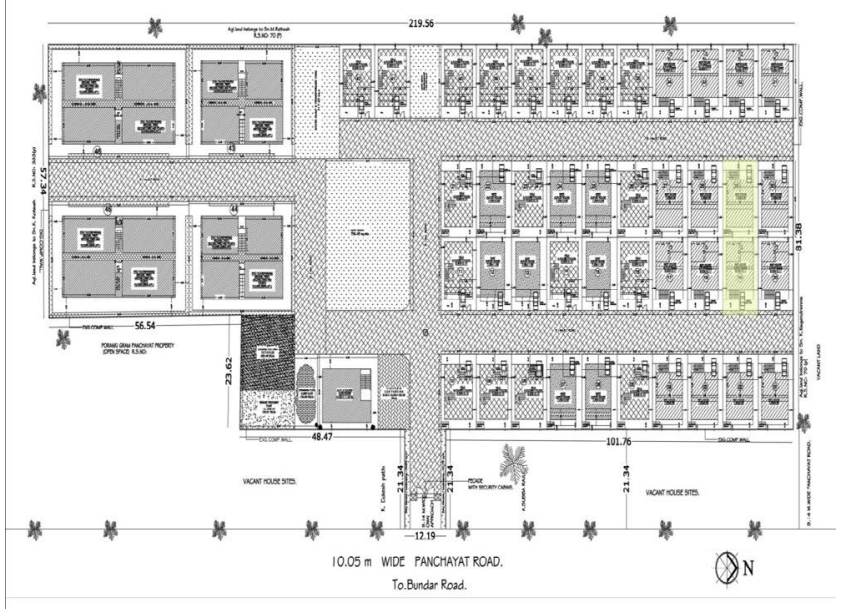

Figure 3. Layout of the gated community.

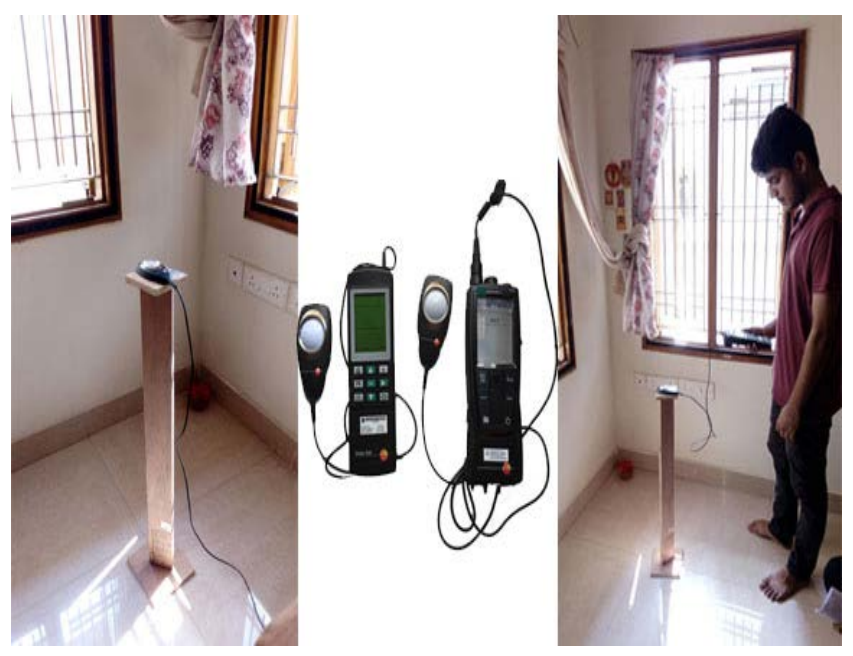

Figure 4. Day lighting measurement.

\subsubsection{Daylighting Measurement Method}

As the day lighting is more in the summer season than the remaining seasons, the case study was conducted in summer i.e., in the month of April 2016. Only the ground floors of the buildings were considered for the study. The illumination was measured with the day lighting 
instruments Test o 480 and Test o 540 (Figure 4), at the working table height while keeping the doors closed. In both the residences, the functional spaces / rooms were divided into $0.6 \mathrm{~m} \times 0.6 \mathrm{~m}$ size grids. These functional spaces include one drawing/living hall, one dining hall, two bedrooms and one kitchen of the ground floors. The readings were taken at the identified node points (Abbreviated in the floor plan as L - Drawing/Living room, D-Dining, K-Kitchen, MB-Master Bedroom and CB-Children Bedroom. The abbreviated letter is followed by the location node point location number. Eg., L1) at regular distances away from the window openings as in Figure 5. One window for each functional space was considered for measurement. The illumination was measured at six regular intervals of the day (i.e., 6.00am-8.00am, 8.00am-10.00am, 10.00am-12.00pm, and $12.00 \mathrm{pm}-200$ $\mathrm{pm}, 2.00 \mathrm{pm}-4.00 \mathrm{pm}$ and $4.00 \mathrm{pm}-6.00 \mathrm{pm})$ for the identified windows of different sides. The details of each of the samples are discussed below:

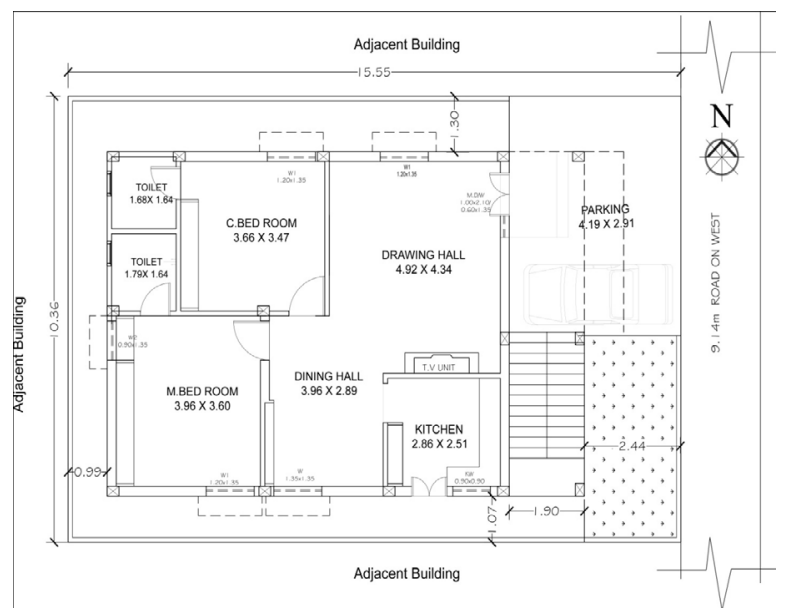

Figure 4. Sample 1- Ground floor plan.

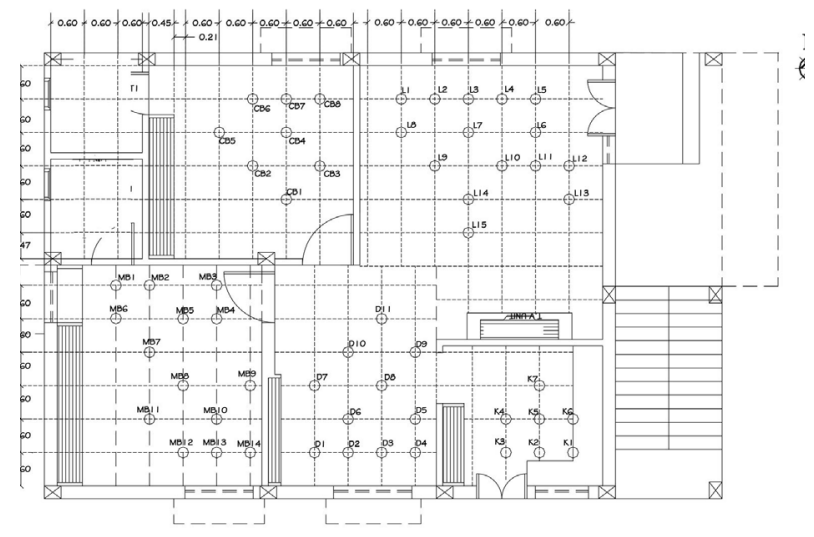

Figure 5. Sample 1- Floor plan showing the identified nodes for day lighting measurement.

\subsubsection{Sample-1: East Facing Residence}

Building Profile: This residence (No. 18) is located $\left(80^{\circ} 42^{\prime} 29.14^{\prime \prime} \mathrm{E}, 16^{\circ} 29^{\prime} 1.40^{\prime \prime} \mathrm{N}\right)$ on the northern side of the gated community. The plot area is 161.09 sq. $\mathrm{m}$ with 96.88 sq. $\mathrm{m}$ of the plinth area. The building coverage area in the plot is around $60.1 \%$, with the remaining $39.9 \%$ of the open to sky/setback area. The building is two-floored, constructed around eight years ago. The total height of the building is $4.30 \mathrm{~m}$ (with ground floor height of $2.75 \mathrm{~m}$ and the plinth height of $0.3 \mathrm{~m}$ ). Ground floor plan Figure 4 and details of the setbacks, obstruction distances and the openings are given.

Table 2. Sample 1- Details of setbacks and obstruction distances

\begin{tabular}{|l|l|l|l|}
\hline Orientation & \multicolumn{3}{|l|}{ Sample-1: East facing residence } \\
\cline { 2 - 4 } & Obstruction & $\begin{array}{l}\text { Setback } \\
\text { (in metre) }\end{array}$ & $\begin{array}{l}\text { Obstruction } \\
\text { distance (in } \\
\text { metre) }\end{array}$ \\
\hline East & $\begin{array}{l}\text { Road (9.14 } \\
\text { metre wide) }\end{array}$ & 2.44 & -- \\
\hline West & $\begin{array}{l}\text { Adjacent } \\
\text { building }\end{array}$ & 0.99 & 3.12 \\
\hline North & $\begin{array}{l}\text { Adjacent } \\
\text { building }\end{array}$ & 1.30 & 2.37 \\
\hline South & $\begin{array}{l}\text { Adjacent } \\
\text { building }\end{array}$ & 1.07 & 2.37 \\
\hline
\end{tabular}

Openings: In the Table-3, the existing areas of the openings in each of the rooms are compared against the required minimum opening area as recommended by the AP Building byelaws and the NBC of India 20015.The area of the openings of the bedrooms and the dining hall is more than the recommended values. However in the case of the living hall and kitchen, it is more than the area recommended by the AP building byelaws but lesser than that of the NBC of India 2005.

Illumination Measurement: The node points at which the illumination levels were measured are shown in the plan Figure 5. The average illumination of each of the functional spaces/rooms is taken as the mean of the average illuminations of the node readings at different times of the day in the respective functional space/ room. Depending on the room size the identified number of nodes in each room is different from other rooms. The total number of identified nodes in the residence is 65 with 15 nodes in Living Hall, 11 nodes in Dining Hall, 
Table 3. Sample 1- Details of the openings

\begin{tabular}{|l|l|l|l|l|l|}
\hline S. No. & $\begin{array}{l}\text { Functional } \\
\text { Space/ Room }\end{array}$ & $\begin{array}{l}\text { Area of the } \\
\text { Space } \\
\text { (Sq.mts) }\end{array}$ & $\begin{array}{l}\text { Opening } \\
\text { Provided (Sq. } \\
\text { mts) }\end{array}$ & $\begin{array}{l}\text { Opening required } \\
\text { as per NBC } \\
\text { 2005(Sq.mts) }\end{array}$ & $\begin{array}{l}\text { Opening required (1/9 } \\
\text { carpet area) as per A.P } \\
\text { G.O.Ms. 168(Sq.mts) }\end{array}$ \\
\hline 1 & Living & 21.35 & 2.43 & 2.66 & 2.37 \\
\hline 2 & M. Bed Room & 14.25 & 2.83 & 1.78 & 1.54 \\
\hline 3 & C. Bed Room & 12.70 & 1.62 & 1.59 & 1.41 \\
\hline 4 & Kitchen & 7.17 & 0.81 & 0.89 & 0.79 \\
\hline 5 & Dining & 10.66 & 1.82 & 1.33 & 1.18 \\
\hline
\end{tabular}

Table 4. Sample 1- Average illumination levels

\begin{tabular}{|l|l|l|l|l|l|l|l|l|}
\hline & $\begin{array}{l}\text { Average } \\
\text { illumination } \\
\mathbf{6 . 0 0 - 8 . 0 0} \\
\text { (in Lux) }\end{array}$ & $\begin{array}{l}\text { Average } \\
\text { illumination } \\
\mathbf{8 . 0 0 - 1 0 . 0 0} \\
\text { (in Lux) }\end{array}$ & $\begin{array}{l}\text { Average } \\
\text { illumination } \\
\mathbf{1 0 . 0 0 - 1 2 . 0 0} \\
\text { (in Lux) }\end{array}$ & $\begin{array}{l}\text { Average } \\
\text { illuminatio } \\
\mathbf{n} \\
\mathbf{1 2 . 0 0 - 2 . 0 0} \\
\text { (in Lux) }\end{array}$ & $\begin{array}{l}\text { Average } \\
\text { illumination } \\
\mathbf{2 . 0 0 - 4 . 0 0} \\
\text { (in Lux) }\end{array}$ & $\begin{array}{l}\text { Average } \\
\text { illumination } \\
\mathbf{4 . 0 0 - 6 . 0 0} \\
\text { (in Lux) }\end{array}$ & $\begin{array}{l}\text { Average } \\
\text { Illumination } \\
\text { of the day } \\
\text { (in Lux) }\end{array}$ & $\begin{array}{l}\text { Required } \\
\text { Illumination } \\
\text { (in Lux) }\end{array}$ \\
\hline $\begin{array}{l}\text { Average } \\
\text { outside } \\
\text { daylight }\end{array}$ & 1140 & 25757 & 85327 & 94000 & 74729 & 36428 & 52896.83 & $9000^{\star}$ \\
\hline Living & 22.40 & 95.13 & 355.33 & 377.87 & 246.07 & 96.67 & 198.91 & 150 \\
\hline Dining & 12.00 & 74.55 & 190.73 & 139.09 & 117.55 & 62.73 & 99.44 & 100 \\
\hline $\begin{array}{l}\text { M. } \\
\text { Bedroom }\end{array}$ & 4.29 & 47.36 & 149.50 & 178.36 & 174.64 & 110.50 & 110.77 & 100 \\
\hline C. Bedroom & 54.87 & 99.25 & 233.13 & 340 & 233.25 & 77.87 & 173.06 & 100 \\
\hline Kitchen & 8.57 & 62.00 & 93.43 & 51.14 & 57.43 & 19.86 & 48.74 & 200 \\
\hline
\end{tabular}

${ }^{\star}$ recommended design sky luminance value as NBC of India 2005

eight nodes in Children Bedroom, 14 nodes in Master Bedroom, and seven nodes in Kitchen.

The day lighting measurement was done on April 16, 2016. On this day, the external daylight factor ranged between $1140 \mathrm{lux}$ at $6.00 \mathrm{am}$ and $36,428 \mathrm{lux}$ at $6.00 \mathrm{pm}$. The average illuminations at each time interval of the day, in each of the functional spaces, are presented in the table and are also shown graphically:

\section{Key Observations}

Living Room: The average illumination is found to be above the recommended values. It is above the required values only during $10.00 \mathrm{am}$ and $4.00 \mathrm{pm}$, while it is lesser during the remaining part of the day. The illumination levels are more near the window than away from the window. A major portion of the living room suffers from poor illumination levels, despite large window opening size which is above the recommended values of AP building byelaws Table-3. Also, the diffused lighting from the north could be one of the reasons for this phenomenon.

Kitchen: The average illumination in the kitchen is found to be very less. It is almost lesser than one-fourth of the required levels. A major portion of the kitchen suffers from poor illumination despite adequate window opening size. It may be noted that the window of the kitchen is south facing. This phenomenon can be attributed to the smaller setback on the south side. However, illumination is good during $10.00 \mathrm{am}$ and $4.00 \mathrm{pm}$.

Dining Hall: It is almost the same as the recommended value. The illumination is good only during $10.00 \mathrm{am}$ and $4.00 \mathrm{pm}$. Location of its window on the south side (with smaller setback) could be one of the reasons for the poor indoor day lighting. Bedrooms: The average illumination level is above the minimum required values in 
the children bedroom and just above in the case of master bedroom. While in the case of the children bedroom, the room is being utilised as study room, causing them inconvenience in performing their activity.

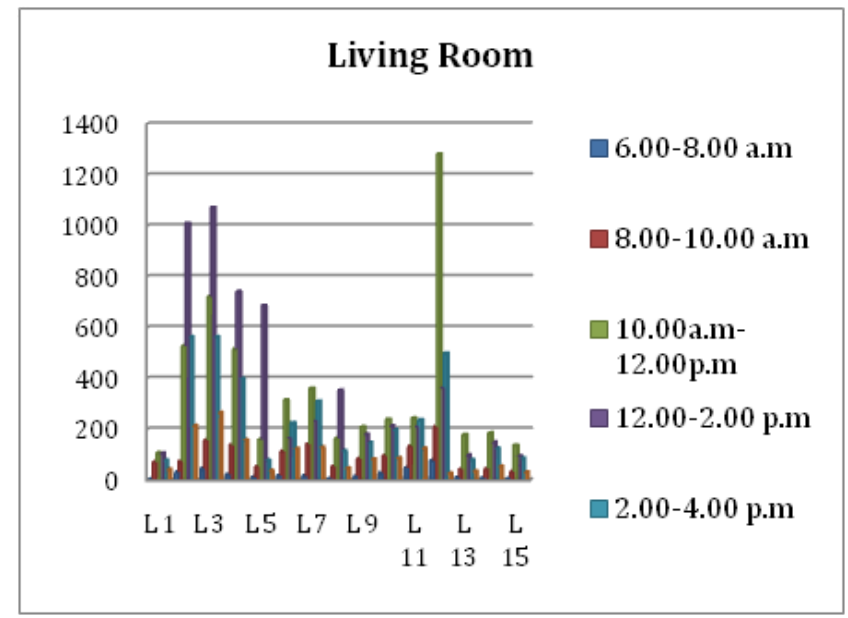

Figure 6. Sample 1- Illumination in the Living Hall (where L1, L2... are the node points for measurements) Source: Authors.

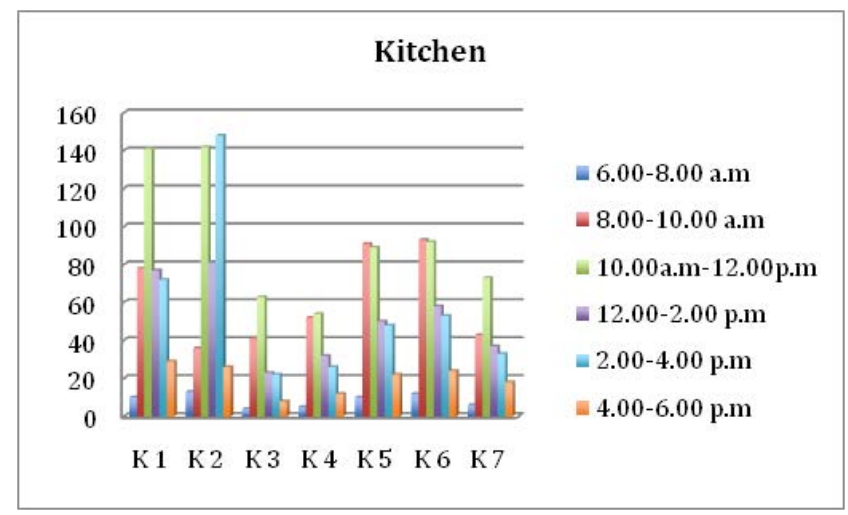

Figure 7. Sample 1- Illumination in the Kitchen (where $\mathrm{K} 1, \mathrm{~K} 2 \ldots$ are the node points for measurements) Source: Authors.

\section{Key Learning's:}

The following are a few reasons identified for poor / insufficient indoor illumination levels:

- Smaller setback: It may be noted that the major windows of kitchen, master bedroom and the dining hall are south facing. In comparison to other rooms, the average illumination levels in these rooms are lesser.

- Diffused lighting: A major portions of the interior spaces were found to be affected due to diffused lighting.
- Smaller window openings: Despite following the recommended minimum required window opening sizes, the indoor illumination is poor. Therefore, there is need to re-consider the recommended minimum window opening sizes in line with the respective setback.

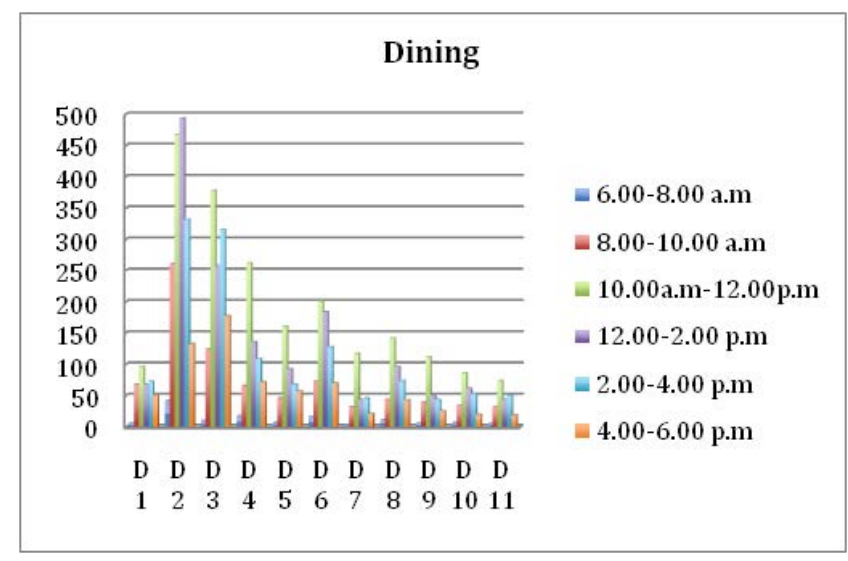

Figure 8. Sample 1- Illumination in the Dining Hall (where D1, D2... are the node points for measurements) Source: Authors.

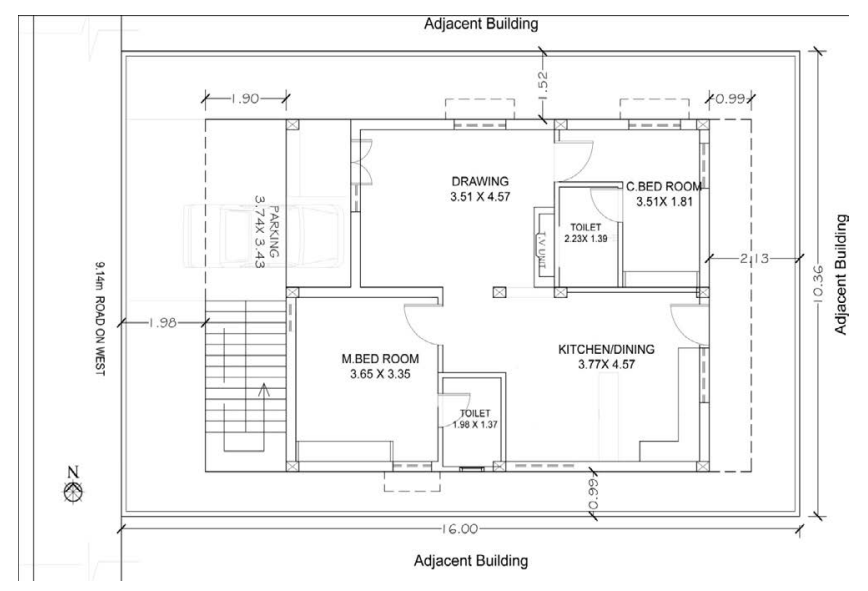

Figure 9. Sample 2- Ground floor plan.

\subsubsection{Sample-2: West Facing Residence}

Building Profile: This residence (No. 29) is located $\left(80^{\circ} 42^{\prime} 29.14^{\prime \prime} \mathrm{E}, 16^{\circ} 29^{\prime} 1.40^{\prime \prime} \mathrm{N}\right)$ on the northern side of the gated community. The plot area is 165.76 sq.m with 101.02sq.m of the plinth area. The building coverage area in the plot is around $60.9 \%$, with the remaining $39.1 \%$ of the open to sky/ setback area. The building is two-floored, constructed around eight years ago. The total height of the building is $4.30 \mathrm{~m}$ (with ground floor height of $2.75 \mathrm{~m}$ and the plinth height of $0.3 \mathrm{~m}$ ). Ground floor plan and 
Table 5. Sample 2- Details of setbacks and obstruction distances

\begin{tabular}{|l|l|l|l|}
\hline \multirow{2}{*}{ Orientation } & \multicolumn{2}{|l|}{ Sample-2: West facing residence } \\
\cline { 2 - 4 } & Obstruction & $\begin{array}{l}\text { Setback (in } \\
\text { metre) }\end{array}$ & $\begin{array}{l}\text { Obstruction } \\
\text { distance (in metre) }\end{array}$ \\
\hline East & Adjacent building & 2.13 & 3.12 \\
\hline West & $\begin{array}{l}\text { Road (9.14 metre } \\
\text { wide) }\end{array}$ & 1.98 & -- \\
\hline North & Adjacent building & 1.52 & 2.51 \\
\hline South & Adjacent building & 0.99 & 2.51 \\
\hline
\end{tabular}

Table 6. Sample 2- Details of the openings

\begin{tabular}{|l|l|l|l|l|l|}
\hline $\begin{array}{l}\text { S. } \\
\text { No. }\end{array}$ & $\begin{array}{l}\text { Functional } \\
\text { Space/ Room }\end{array}$ & $\begin{array}{l}\text { Area of the } \\
\text { Space (Sq.mts) }\end{array}$ & $\begin{array}{l}\text { Opening } \\
\text { Provided (Sq. } \\
\text { mts) }\end{array}$ & $\begin{array}{l}\text { Opening required } \\
\text { as per NBC } \\
\text { 2005(Sq.mts) }\end{array}$ & $\begin{array}{l}\text { Opening required (1/9 } \\
\text { carpet area) as per A.P } \\
\text { G.O.Ms. 168(Sq.mts) }\end{array}$ \\
\hline 1 & Living & 16.04 & 2.43 & 2.00 & 1.78 \\
\hline 2 & M. Bed Room & 12.23 & 2.03 & 1.53 & 1.35 \\
\hline 3 & C. Bed Room & 6.35 & 2.84 & 0.79 & 0.71 \\
\hline 4 & $\begin{array}{l}\text { Kitchen/ } \\
\text { Dining }\end{array}$ & 17.22 & 2.90 & 2.15 & 1.91 \\
\hline
\end{tabular}

details of the setbacks, obstruction distances. Table 5 and the openings Table 6 are given below:

Openings: In the Table- 6 , the existing areas of the openings in each of the rooms are compared against the required minimum opening area as recommended by the AP Building byelaws and the NBC of India 20015. The area of the openings of the all the rooms is more than the recommended values.

Illumination Measurement: The node points at which the illumination levels were measured are shown in the plan Figure 10.The average illumination of each of the functional spaces/rooms is taken as the mean of the average illuminations of the node readings at different times of the day in the respective functional space/ room. Depending on the room size the identified number of nodes in each room is different from other rooms. The total number of identified nodes in the residence is 57 with 17 nodes in Living Hall, 19 nodes in Kitchen/ Dining Hall, seven nodes in Children Bedroom and 14 nodes in Master Bedroom.

The day lighting measurement was done on April 16, 2016. On this day, the external daylight factor ranged between 1140 lux at $6.00 \mathrm{am}$ and 36,428 lux at $6.00 \mathrm{pm}$ Table 7. The average illuminations at each time interval of the day, in each of the functional spaces, are presented in the table and are also shown graphically:

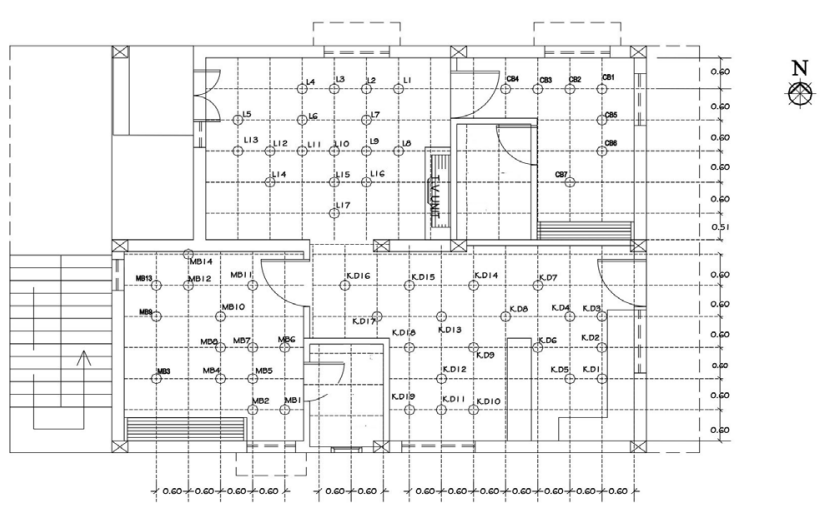

Figure 10. Sample 2- Floor plan showing the identified nodes for day lighting measurement.

\section{Key Observations:}

Living Room: The average illumination (99.2 lux) is found to be lesser than the recommended value (150 lux). It is below the required values at all times of the day. The illumination levels at nodes (L2, L3, L4 and L5) which are 
Table 7. Sample 2- Average illumination levels

\begin{tabular}{|c|c|c|c|c|c|c|c|c|}
\hline & $\begin{array}{l}\text { Average } \\
\text { illumination } \\
6.00-8.00 \\
(\text { in Lux) }\end{array}$ & $\begin{array}{l}\text { Average } \\
\text { illumination } \\
8.00-10.00 \\
\text { (in Lux) }\end{array}$ & $\begin{array}{l}\text { Average } \\
\text { illumination } \\
10.00-12.00 \\
\text { (in Lux) }\end{array}$ & $\begin{array}{l}\text { Average } \\
\text { illumination } \\
12.00-2.00 \\
\text { (in Lux) }\end{array}$ & $\begin{array}{l}\text { Average } \\
\text { illumination } \\
2.00-4.00 \\
\text { (in Lux) }\end{array}$ & $\begin{array}{l}\text { Average } \\
\text { illumination } \\
4.00-6.00 \\
\text { (in Lux) }\end{array}$ & $\begin{array}{l}\text { Average } \\
\text { Illumination } \\
\text { of the day } \\
\text { (in Lux) }\end{array}$ & $\begin{array}{l}\text { Required } \\
\text { Illumination } \\
\text { (in Lux) }\end{array}$ \\
\hline $\begin{array}{l}\text { Average } \\
\text { outside } \\
\text { daylight }\end{array}$ & 1140 & 25757 & 85327 & 94000 & 74729 & 36428 & 52896.83 & $9000^{*}$ \\
\hline Living & 30.41 & 99.06 & 91.59 & 110.71 & 95.53 & 56.41 & 99.22 & 150 \\
\hline $\begin{array}{l}\text { Dining / } \\
\text { Kitchen }\end{array}$ & 60.63 & 90.63 & 134.88 & 167.94 & 123.94 & 37.50 & 102.58 & 200 \\
\hline $\begin{array}{l}\text { M. Bed } \\
\text { room }\end{array}$ & 63.82 & 138.73 & 112.55 & 144.73 & 131.82 & 111.18 & 127.80 & 100 \\
\hline $\begin{array}{l}\text { C. Bed } \\
\text { room }\end{array}$ & 189.43 & 353.86 & 261.00 & 510.14 & 435.57 & 166.29 & 319.88 & 100 \\
\hline
\end{tabular}

${ }^{*}$ recommended design sky luminance value as NBC of India 2005

nearer the window are more than those away from the window Figure 11. The remaining portion of the living room suffers from poor illumination levels, despite large window opening size which is above the recommended values of AP building byelaws Table 3. Also, the diffused lighting from the north could be one of the reasons for this phenomenon.

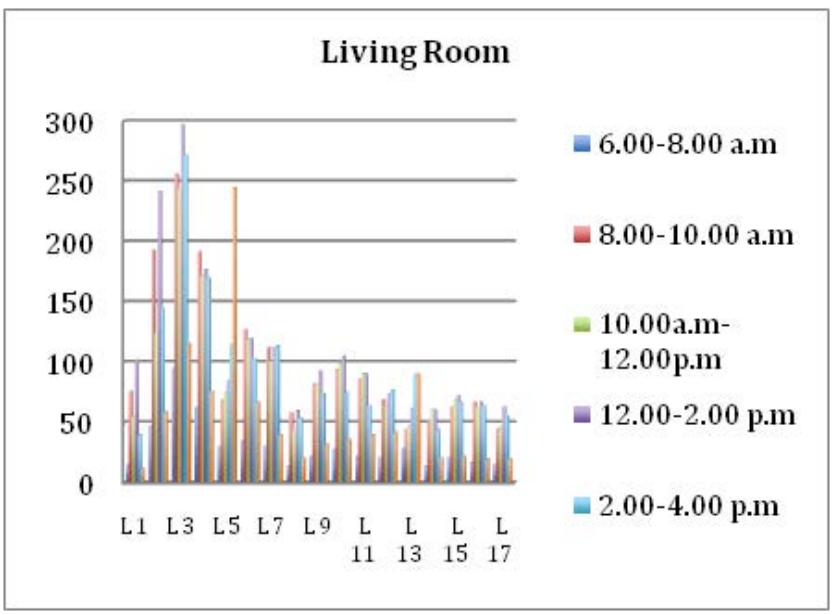

Figure 11. Sample 2- Illumination in the Living Hall (where L1, L2... are the node points for measurements) Source: Authors.

Kitchen/Dining: The average illumination in the kitchen/dining is found to be very less. It is almost lesser than half (102.58) of the required levels (200) Figure 12. A major portion of the kitchen/dining suffers from poor illumination despite adequate window openings, despite a large setback on the eastern side. However, the window of the dining area is located on the south side wall. This could be one of the reasons for a poor indoor illumination.

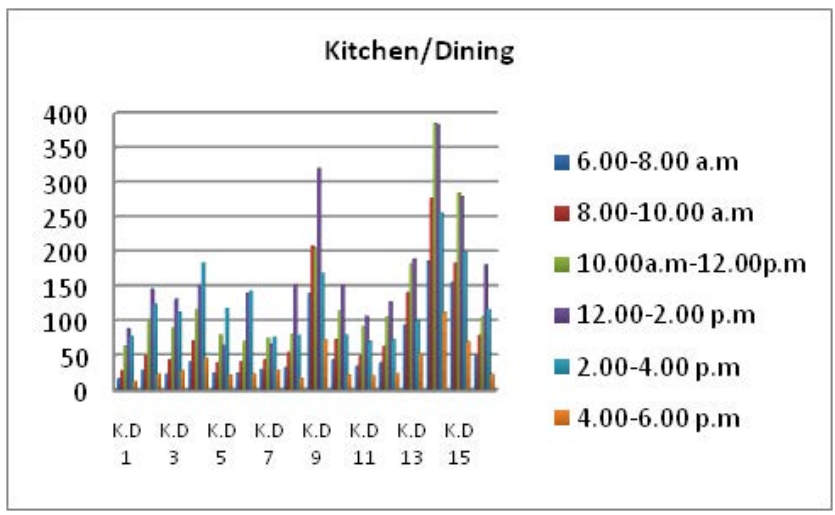

Figure 12. Sample 2- Illumination in the Kitchen/ Dining (where K.D1, K.D2 ... are the node points for measurements) Source: Authors.

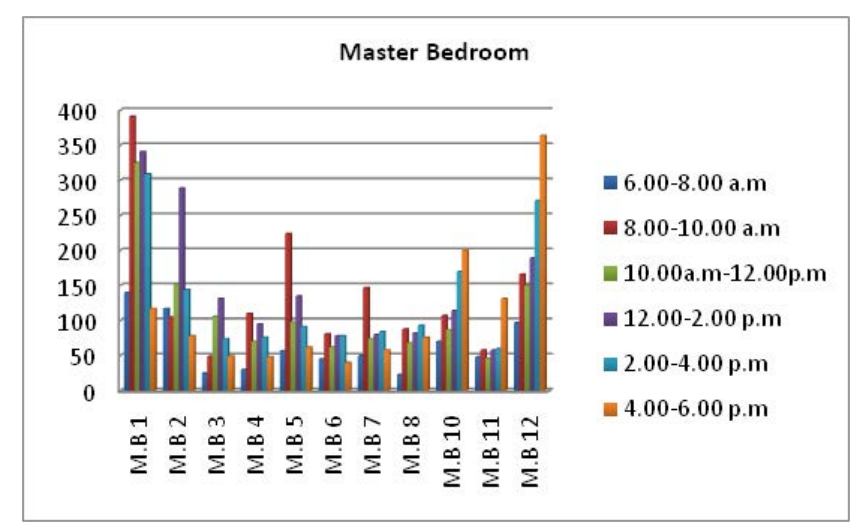

Figure 13. Sample 2- Illumination in the Master Bedroom (whereM.B1, M.B2... are the node points for measurements) Source: Authors. 


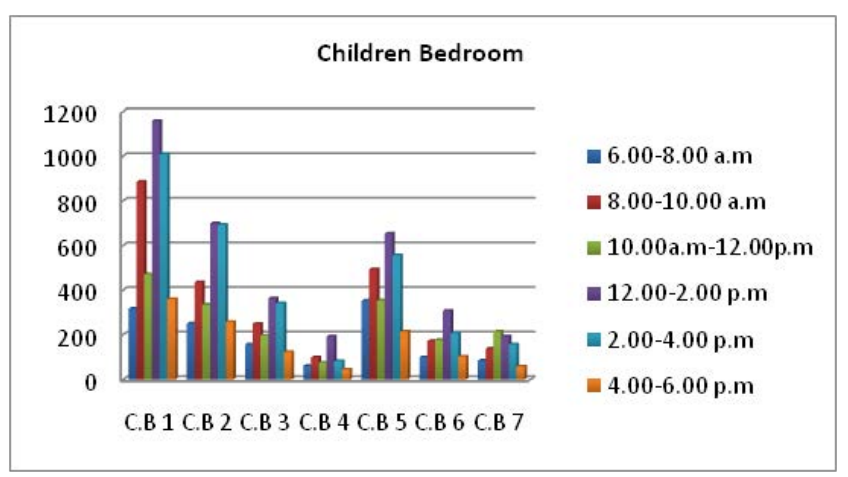

Figure 14. Sample 2- Illumination in the Children Bedroom (whereC.B1, C.B2... are the node points for measurements) Source: Authors.

Master Bedroom: The average illumination level (127.8 lux) is above the minimum required value (100lux) in the master bedroom. The illumination is poor only during 6.00am and 8.00am Figure 13.

Children Bedroom: The average illumination level (319.88 lux) is almost three times more than the minimum required value (100 lux) in the children bedroom Figure 14. This is because of the availability of two windows and small width of the room $(1.81 \mathrm{~m})$.

Key Learning's: The following are a few reasons identified for uncomfortable indoor illumination levels:

- Smaller setback: Despite larger window sizes, rooms suffer from poor illumination due to the smaller setback.

- Diffused lighting: A major portions of the interior spaces were found to be affected due to diffused lighting.

- Smaller room width: Smaller width of the room is found to be uncomfortable due to more than the required lux levels.

\section{Conclusion}

The readings of the indoor illumination in each of the functional spaces showed variations mainly due to the window opening size and the setback/ obstruction distance. The other factors include time of the readings, room width, diffused lighting and the building orientation. Although the setbacks and window opening sizes are in accordance with the local building byelaws, major portions of the functional spaces/ rooms (particularly away from the window) suffer from poor indoor natural illumination levels. Due to the location and size of the window, daylight reflected from the adjacent obstructions does not penetrate deep into the interior spaces leading to poor indoor illumination levels. As a result, the residents depend on artificial lighting.

\section{Recommendations}

1. It is recommended to split the window opening area, while maintaining the window wall ratio as per the building byelaws, place them at different locations of the walls complementing the functional activity of the respective rooms/spaces and for even distribution of light.

2. It is recommended to have windows on adjacent / opposite walls (as per the design feasibility) instead on the same wall.

3. It is advisable to have two windows for each of the functional spaces (as per the design feasibility) so as to admit good indoor illumination levels.

4. It is suggested to re-consider the recommended minimum window opening sizes (by the building byelaws/ NBC) in line with the respective setback.

5. Side lighting is preferred than the sky lighting for this type of climate. This is because of the associate disadvantages with the sky lighting such as less visual contact with the exterior spaces.

6. It is recommended to have light shelves in spaces suffering from poor illumination and where the window area/ setbacks cannot be altered due to site constraints, as the light shelves contribute significantly for comfortable illumination.

7. It is recommended to consider design of the windows with reference to the functional spaces.

\section{References}

1. Li DHW, Wong SL, Tsang CL, Cheung GHW. A study of the day lighting performance and energy use in heavily obstructed residential buildings via computer simulation techniques. Energy and Buildings. 2006; 38(11):1343-8. Crossref

2. McGrath R, Frost AC. Glass in Architecture and Decoration. London: London: Architectural Press; 1961. PMCid:PMC1465909

3. Lam JC. A survey of existing residential buildings and envelope designs in Hong Kong. International Journal for Housing Science and Its Applications. 1994; 18(2):113-24. 
4. Munoz C, Esquivias P, Moreno D, Acosta I, Navarro J. Climate-based day lighting analysis for the effects of location, orientation and obstruction. Lighting Research and Technology. 2014; 46(3):1-35. Crossref

5. Kumar V. All you wanted to know about Vastushastra. First edition. New Delhi: Sterling Publishers Private Ltd; 1999.

6. Bureau of Indian Standards. National Building Code of India. New Delhi: Bureau of Indian Standards. 2005; 1:1-12.

7. Afroz R, Rahman M, Islam KT, Ahmed M. Day light Performance in South Facing Rooms of Residential Apartments In Respect of Current Building Code Relation between Obstruction Distance and Opening Size. European Scientific Journal. 2014; 10(6):1-14.
8. Ruparel A. Indoor Environment in Tall Residential Buildings Mumbai. Architecture Update; 2009. p. 1-7.

9. AltanH, Mohelnikova J. Windows Influence on Room Day lighting in Residential Buildings. Journal of Civil Engineering and Architecture (online). 2015; 9(3):1-9.

10. Jaber S, Ajib S. Thermal and economic windows design for different climate zones. Energy and Buildings. 2011; 43(32):8-15.

11. Almssad A, Almusaed A. Efficient day lighting approach by means of light-shelve device adequate for habitat program in Aarhus City. International Journal of Smart Grid and Clean Energy. 2014; 3(4):441-53. 